\title{
Social network big data analysis as a tool for preventing extremism on the Internet in the interests of sustainable development
}

\author{
Xhevdet Thaqi $^{1}$, Eugeniy Shchekotin ${ }^{2}$, Dmitry Kaznacheev ${ }^{3,}$, , Nadezhda Kaznacheeva ${ }^{3}$, and \\ Natalia Kaznacheeva ${ }^{3}$ \\ ${ }^{1}$ University 'Kadri Zeka', Zija Shemsiu Str., 60000 Gjilan, Kosovo \\ ${ }^{2}$ Novosibirsk State University of Economics and Management, Kamenskaya Str., 56, 630099 \\ Novosibirsk, Russia \\ ${ }^{3}$ Siberian State University of Telecommunications and Information Sciences, Kirova Str., 86, 630102 \\ Novosibirsk, Russia
}

\begin{abstract}
The crisis caused by the COVID-19 pandemic, as well as the migration policies of various countries around the world, lead to the radicalization of the most marginal social groups, including right - wing extremists. Due to the development of information technologies, rightwing extremists receive new channels for spreading their destructive ideas. Since the main users of data networks are young people, primarily schoolchildren and students, the prevention of extremism in public social media is particularly relevant. The authors of the article believe that an effective tool for preventing extremism is the collection and processing of data on the activity of right-wing radicals in social networks. Such work, according to the authors, can not only increase the effectiveness of identifying extremists on the Internet, but also establish productive interaction with the main target audience of social media - young people. In the interests of sustainable development, it is necessary to cooperate with authorities, technical specialists, and educational institutions in order to develop a unified policy to counter extremism both in the Sverdlovsk region and in Russian Federation and around the world.
\end{abstract}

\section{Introduction}

Against the background of the growing terrorist threat in Europe, Asia and North Africa, the fight against terrorism and extremism should be an initiating and unifying factor in the development of joint coordinated actions by states. In this regard, the study of foreign national and supranational experience of the EU countries in the field of countering terrorism and extremism is relevant not only for the Russian Federation, but also for the Eurasian integration unions with the participation of Russian Federation.

Deputy Secretary of the Security Council of the Russian Federation Alexander Grebenkin said in an interview with 'Rossiyskaya Gazeta' that the number of extremist crimes is growing in a difficult socio-economic situation caused, among other things, by the

*Corresponding author: 3335799@gmail.com 
coronavirus pandemic. According to Grebenkin, about half of these offenses are related to calls for extremism on the Internet [1].

According to the materials of the Portal of Legal Statistics of the Prosecutor General's office of the Russian Federation, the number of extremist crimes in the Sverdlovsk region from January to August 2020 increased by $733.3 \%$ compared to the same period last year $[2]$.

Back in 2019, the head of Ekaterinburg, Alexander Vysokinsky, signed a decree on the creation of an interdepartmental Commission for the prevention of extremism in the city. As stated in the document published on the administration's website, the Commission makes decisions on the work of local governments to implement measures to prevent extremism, prepares recommendations on this issue, and analyzes the effectiveness of the measures taken.

The Commission includes several heads of departments of the Federal Security Service of the Sverdlovsk region, and a number of key city hall officials. Obviously, this indicates the relevance of the fight against extremism, including on the Internet, in the light of the prospects for sustainable development of the Sverdlovsk region and Ekaterinburg [3].

Actually, extremists use technology and cyberspace to create technology to propagate their thinking crimes. And they are continuously supported from various sources, primarily misusing modern technology for funding or Command and Control purposes.

Prevention of violent extremism in Russian Federation is an important and necessary requirement for the country. Today's asymmetric warfare requires newer tools and techniques to keep pace with the changing times. Big data processing is evolving as a very effective and well-established technique in counter-terrorism and is the way ahead for Russian law enforcement agencies to undertake 'predictive counter-terrorism' measures so as to prevent violent extremism.

Preventing extremism on the Internet requires a well-coordinated joint work of government and management bodies, information technology and big data specialists, and educational institutions.

Table 1. Some of right-wing extremist communities in the VK social network

\begin{tabular}{|l|l|l|l|l|}
\hline Community & Link & $\begin{array}{l}\text { Number of members } \\
\text { (as of March 31, } \\
\mathbf{2 0 1 9 )}\end{array}$ & $\begin{array}{l}\text { Number of } \\
\text { posts }\end{array}$ & $\begin{array}{l}\text { Average } \\
\text { number of } \\
\text { posts per } \\
\text { day }\end{array}$ \\
\hline $\begin{array}{l}\text { Blood of the } \\
\text { North (Krov' } \\
\text { Severa) }\end{array}$ & $\begin{array}{l}\text { https://vk.com/public } \\
41324303\end{array}$ & 32127 & 409 & 4.5 \\
\hline $\begin{array}{l}\text { Hatchet } \\
\text { (Tesak) }\end{array}$ & $\begin{array}{l}\text { https://vk.com/public } \\
15711409\end{array}$ & 32500 & 433 & 9.2 \\
\hline $\begin{array}{l}\text { Praise Rus' } \\
\text { (Slava Rusi) }\end{array}$ & $\begin{array}{l}\text { https://vk.com/slavaru } \\
\text { sam }\end{array}$ & 13635 & 250 & 35.7 \\
\hline $\begin{array}{l}\text { The Right } \\
\text { (Pravyie) }\end{array}$ & $\begin{array}{l}\text { https://vk.com/rus.pra } \\
\mathrm{v}\end{array}$ & 141557 & 150 & 1.7 \\
\hline
\end{tabular}

The analysis of the impact of information distributed in social networks on people's social behavior and the state of society as a whole on the basis of technologies for working with 'big data' is of particular importance. The laboratory of big data science and social problems at Tomsk State University has been developing methods for collecting data on 
extremist communities in social networks for several years. In particular, the laboratory works in the direction of studying the self-presentation of right-wing extremist communities in the VK social network (Table 1).

\section{Methods, approaches and tools for studying extremist communities in social networks}

Methodologically, we considered it appropriate to use the Critical Discourse Analysis (CDA). CDA is the most widespread; Wodak and van Dijk are the well-known representatives of this approach. The goal of the critical discourse analysis can be generally described as follows.

It is an utterly transparent analysis criticizing connections between properties of texts, social processes and relations (ideologies, power relations), which are normally not obvious to people who generate and interpret those texts, and whose effectiveness depends upon this capacity [4].

Reisigl and Wodak [5] analyze four discourse-analytical approaches to the studies of extremism:

1) Prejudices and stereotypes (U. Quasthoff). Quasthoff studies the origins of social prejudice and stereotypes in relation to some groups resting upon the psychological explanation of this phenomenon; the discursive discrimination maintains the internal integrity of some social groups [6].

2) Socio-cognitive discourse-analytical approach (T. van Dijk). van Dijk generally shares the stipulations of the social-psychological approach of Quasthoff to discrimination, where he includes manifestations of racism, ethnicism, etc. discrimination, in van Dijk's view, is a form of social representativeness of the group members. It arises in the course of socialization and is brought into play during social intercourse and interaction. Cognitive structures and strategies of the ethnical relationships reflect the social functions performed by these forms of representation [7].

3) Discourse strands and collective symbols (so called Duisburg group, S. and M. Jäger). This approach is a logical explanation of van Dijk's views on racism. In particular, it explains the social functions of the racist discourse. This approach is focused on studies of collective symbols and collective stereotypes [8].

4) Loughborough group (M. Wetherell and J. Potter). Wetherell and Potter believe that racism is not static and homogeneous; it is a series of ideological effects with variable and diverse contents [9].

To analyze the visual and discursive self-presentation of the right-wing radicals we have selected 4 communities for each of the ideologies from VK, the most popular Russian social network. In our previous study we applied the methods of automated search for extremist communities to detect and analyze 42 communities with right-wing radical contents. The most radical of them are banned now due to the censorship considerations.

In each of the two segments of radical movements we have selected the communities (Table 1), corresponding to the following criteria:

1) They should be large enough as compared to the other communities with similar ideology.

2) They should publish posts on the regular basis, at least 1 post every other day, for the last year.

3) They should present different fields and ideological views in the right-wing radical and Islamist movements.

We have analyzed posts from these communities. For Blood of the North (Krov' Severa) and The Right (Pravyie) we have analyzed all posts published within the period between January 01 to March 31, 2019, while for Hatchet (Tesak) we have analyzed the 
posts published within the period between February 13 to March 31, 2019. For Praise Rus' (Slava Rusi) we have analyzed the posts published within the period between March 25 and 31. We have selected such time frames based on the frequency of publishing. For example, the community Praise Rus' (Slava Rusi) publishes 1-2 posts each hour; thus, due to such a huge amount of posts we have taken the publications for 1 week only. Later we have studied the posts and categorized them according to their topics.

We have systematized all posts into several thematic sections, which included publications with similar contents and meaning. We have also determined the emotional mode for each of these sections - negative, positive, neutral. We have categorized thematic sections with predominantly negative emotions in relation to some phenomena, events or personalities as negative. Normally this mode is associated with topics creating an image of external and internal enemies of the extremist communities, their ideological opponents and the social environment perceived as hostile (viciousness of the modern society). The positive mode includes the sections aiming at creation of their own community (instead of the idea to destroy the 'hostile' environment), containing the characteristic of an ideal personality or historical examples of a standard personality for this community, as well as the broader range of topics related to the positive assessment of some events and phenomena of the modern life. The neutral mode includes sections without any definite emotional appraisal (like humor, advertisements, photos of nature, animals, etc.).

All 4 communities are very different in their ideologies; however, there are some common topics present in all of them:

1) Giving up smoking, alcohol consumption, and other harmful habits. All communities we have analyzed express a clear appeal to give up addictions and to adopt healthy lifestyle, to do sports. This statement is presented in different forms and with different motives, but it is always there.

2) The main enemy of Russia is the modern Russian state, the so-called 'Putin's Russia'. It's a paradox, but the right-wing radicals tend to distance themselves from the modern political regime blaming it for all possible vices. Their rejection of the existing political regime is frequently combined with various alternative projects like the libertarian lack of the state, restoration of the Soviet project or of the Russian Empire, some abstract 'state of spirit', but the starting point is always the fact that the modern state (or the modern society, from the pagan point of view) is the reign of 'evil' and decay.

\section{Conclusions}

As is seen from our analysis, the methods of discursive and visual representation of rightwing radicals are approximately identical.

Right-wing radicals are distinguished by the high degree of political engagement, and apply many visual representation methods.

For right-wing radicals, the main enemy is the modern Russian political regime, so in lots of posts the community members criticize this regime.

The common element in all cases we have analyzed is the structured 'conflict discourse'. Firstly, it is characterized by the clear definition of an enemy and demonstration of one's superiority over this enemy. This superiority is moral, intellectual and personal. This enemy is presented disparagingly, so that a supporter of a radical ideology understands malignity and impermissibility of any contacts with this enemy, or there is even clear prohibition of such contacts. Secondly, next to representation of the enemy we see a utopic picture of the 'correct society', of the way life should be. This representation can be secular and retrospective, with memories of the Russian Empire or the USSR, or it can be a representation of some early anarchist pre-state relations [10]. 
Based on the above, institutions and administrations are clearly demanding development of a humanistic learning approach for a hybrid world. The more the Industry 4.0 revolution consolidates its principles of hyper connectivity and hyper mediation, the more young people feel alienated from person-to-person socialization and disaffected from school and other formal educational environments.

To compensate for these situations and undesirable consequences, education systems are including anti-extremist programs in their curriculum. Projects for solving conflicts at school, building empathy, facilitating peer-to-peer tutoring, mediation, no-bullying campaigns, and emotional intelligence for community building are spreading everywhere. The need for relational skills seems to grow among new generations that are extremely connected in virtual spaces [11].

\section{Acknowledgements}

The article has been prepared using the results obtained in the Laboratory of Big Data Science and Social Problems at Tomsk State University.

\section{References}

1. I. Egorov, Rossiyskaya Gazeta, 108 (2020)

2. Monthly Collection On the State of Crime in Russia, 8 (2020)

3. Official portal of Ekaterinburg (2020), https://екатеринбург.рф

4. N. Fairclough, Critical Discourse Analysis. The Critical Study of Language (1995)

5. M. Reisigl, R. Wodak, Discourse and Discrimination: Rhetorics of Racism and Antisemitism (2001)

6. U. M. Quasthoff, Social Pejudice as a Resource of Power: Towards the Functional Ambivalence of Stereotypes (1989)

7. L. Thiesmeyer, Ethics and Information Technology, 2 (1999)

8. Andreas Musolf, Journal of Language Aggression and Conflict, 1 (2015)

9. Jessie Daniels, New Media \& Society, 10 (2012)

10. Myagkov M., Shchekotin E.V, Kashpur V.V, Goiko V.L and Baryshev A.A., East European Politics, 34 (2018)

11. R. Mustafa, K. Mustafa, X. Thaqi, B. Ahmedi, E. Halimi, Innovations, Technologies and Research in Education (2019) 